\title{
Assessment of allelic diversity in intron-containing Mal d I genes and their association to apple allergenicity Zhongshan Gao ${ }^{1,2,3}$, Eric W van de Weg*2,3, Catarina I Matos², Paul Arens ${ }^{3}$, Suzanne THP Bolhaar ${ }^{4}$, Andre C Knulst ${ }^{4}$, Yinghui Li ${ }^{3,5}$, Karin Hoffmann- Sommergruber ${ }^{6}$ and Luud JWJ Gilissen ${ }^{2,3}$
}

\begin{abstract}
Address: ${ }^{1}$ Department of Horticulture/Allergy Research Center, Zhejiang University, Hangzhou 310029, PR China, ${ }^{2}$ Allergy Consortium Wageningen, Wageningen University and Research Centre, P.O. Box 16, 6700AA, Wageningen, the Netherlands, ${ }^{3}$ Plant Research International, Wageningen University and Research Centre, P.O. Box 16, 6700AA, Wageningen, the Netherlands, ${ }^{4}$ Department of Dermatology/Allergology, University Medical Center Utrecht, P.O. Box 85500, 3508GA Utrecht, the Netherlands, ${ }^{5}$ The National Key Facility for Crop Gene Resources and Genetic Improvement (NFCRI)/Key Lab of Germplasm \& Biotechnology (MOA), Institute of Crop Science, China Academy of Agricultural Science, Beijing, 100081, PR China and 'Department of Pathophysiology, Medical University of Vienna, AKH-EBO-3Q, Währinger Gürtel 18-20, A-1090 Vienna, Austria

Email: Zhongshan Gao - gaozhongshan@zju.edu.cn; Eric W van de Weg* - eric.vandeweg@wur.nl; Catarina I Matos - C.Matos@IMMUNO.unimaas.nl; Paul Arens - paul.arens@wur.nl; Suzanne THP Bolhaar - sverleisdonk@viecuri.nl; Andre C Knulst - a.c.knulst@umcutrecht.nl; Yinghui Li - liyhcaaswur@yahoo.com.cn; Karin Hoffmann-Sommergruber - Karin.HoffmannSommergruber@meduniwien.ac.at; Luud JWJ Gilissen - luud.gilissen@wur.nl

* Corresponding author
\end{abstract}

Published: 13 November 2008

Received: 28 November 2007

BMC Plant Biology 2008, 8:116 doi:10.1186/147|-2229-8-1/6

This article is available from: http://www.biomedcentral.com/I47I-2229/8/II6

(c) 2008 Gao et al; licensee BioMed Central Ltd.

This is an Open Access article distributed under the terms of the Creative Commons Attribution License (http://creativecommons.org/licenses/by/2.0), which permits unrestricted use, distribution, and reproduction in any medium, provided the original work is properly cited.

\begin{abstract}
Background: Mal $d \mathrm{I}$ is a major apple allergen causing food allergic symptoms of the oral allergy syndrome (OAS) in birch-pollen sensitised patients. The Mal $d$ I gene family is known to have at least 7 intron-containing and II intronless members that have been mapped in clusters on three linkage groups. In this study, the allelic diversity of the seven introncontaining Mal d I genes was assessed among a set of apple cultivars by sequencing or indirectly through pedigree genotyping. Protein variant constitutions were subsequently compared with Skin Prick Test (SPT) responses to study the association of deduced protein variants with allergenicity in a set of 14 cultivars.
\end{abstract}

Results: From the seven intron-containing Mal d I genes investigated, Mal d I.0I and Mal d I.02 were highly conserved, as nine out of ten cultivars coded for the same protein variant, while only one cultivar coded for a second variant. Mal $d$ I.04, Mal d I.05 and Mal d I.06 A, B and C were more variable, coding for three to six different protein variants. Comparison of Mal $d$ I allelic composition between the high-allergenic cultivar Golden Delicious and the low-allergenic cultivars Santana and Priscilla, which are linked in pedigree, showed an association between the protein variants coded by the Mal d I.04 and - I.06A genes (both located on linkage group 16) with allergenicity. This association was confirmed in 10 other cultivars. In addition, Mal d $1.06 \mathrm{~A}$ allele dosage effects associated with the degree of allergenicity based on prick to prick testing. Conversely, no associations were observed for the protein variants coded by the Mal $\mathrm{d}$ I.OI (on linkage group 13), - I.02, - I.06B, - I.06C genes (all on linkage group 16), nor by the Mal d I.05 gene (on linkage group 6).

Conclusion: Protein variant compositions of Mal d I.04 and - I.06A and, in case of Mal d I.06A, allele doses are associated with the differences in allergenicity among fourteen apple cultivars. This information indicates the involvement of qualitative as well as quantitative factors in allergenicity and warrants further research in the relative importance of quantitative and qualitative aspects of $\mathrm{Mal} d$ I gene expression on allergenicity. Results from this study have implications for medical diagnostics, immunotherapy, clinical research and breeding schemes for new hypo-allergenic cultivars. 


\section{Background}

Many birch pollen sensitised patients (50-70\%) in Central and Northern Europe suffer from oral allergy symptoms after eating fresh apples [1]. The prevalence of apple allergic individuals mounts up to $\sim 3 \%$ in Central and Northern Europe. This type of apple allergy is caused by cross reactivity of IgE antibodies against the major and sensitizing birch pollen allergen Bet v 1 with Mal d 1, the major allergen of apple. Bet $\mathrm{v} 1$ and Mal $\mathrm{d} 1$ are both pathogenesis-related (PR) proteins. They belong to the PR-10 family and share a high degree of homology [2-6].

From patients' experience it is known for a long time that the severity of allergic reactions to apple was not only related to the specific sensitivity of the individual, but also largely depended on the apple cultivar. This cultivar dependent allergenicity has also been described in literature. For instance, Mal d 1 from the cultivar Golden Delicious was found highly reactive to specific IgE antibodies from allergic patients' sera, whereas Mal d 1 from the cultivar Gloster generally showed much less reactivity $[7,8]$. In addition, skin prick testing (SPT) with 21 different apple cultivars and confirmations for specific cultivars in double-blind placebo-controlled food challenges (DBPCFC) and oral challenges of whole apples, revealed a wide range of allergenic reactivity from very high to very low $[9,10]$. As a result from these studies, the new cultivar Santana was identified as hypo- allergenic for 75\% of the patients with a mild apple allergy [10], which is usually assumed to be Mal d 1 based. In The Netherlands (where birch pollen-related apple allergy is by far the most common form of apple allergy), this cultivar has recently been marketed as 'suited for individuals with mild apple allergy' in order to meet the general desire of apple allergic persons to be able to add this common fruit to their daily diet.

The differences in allergenicity among cultivars raised a crucial question on the origin of this cultivar-specific degree of allergenicity. Allergenicity may depend on the total amount of Mal d 1 proteins, as suggested by Son et al. [11] from their observed ten-fold difference in Mal d 1 amount between the high-allergenic cultivar Golden Delicious and the low-allergenic cultivar Gloster. However, there is little evidence supporting this hypothesis because only very few cultivars have been studied and, for these, a linear response between Mal d 1 protein content and allergenicity estimates is lacking. On the other hand, qualitative characteristics of the Mal d 1 proteins could be involved too, as can be argued from the differences in binding capacity of birch pollen-specific IgE to two protein variants of Mal d 1 [11-13]. To elaborate this latter issue, research on the genetic variation of Mal d 1 and its expression pattern in the different cultivars is required and should be compared to allergenicity data. It is known that
Mal d 1 is coded by a large gene family of 18 members mapped on three linkage groups of the apple genome $[14,15]$. Not all of these members are likely to be involved in allergenicity since only a limited number of different Mal d 1 proteins and mRNAs have been traced back in apple fruit so far [16-18].

Research towards the relative importance of the quality and quantity of Mal d 1 proteins on the allergenicity of apple cultivars is relevant for designing apple breeding programs for low-allergenic apple cultivars of high quality and healthiness. In this paper, we focused on the genetic diversity of Mal $d 1$ genes. The Mal $d 1$ gene family can be subdivided into two major categories: genes with and genes without an intron. Preliminary genetic analyses revealed that the genetic diversity was by far larger in the intron-containing genes. Furthermore, the intron-containing genes cover all three linkage groups that Mal $d 1$ loci [15]. Therefore, this category of genes has been chosen to start looking for putative qualitative effects of Mal d 1 proteins in cultivar specific allergenicity.

Allelic diversity of the seven intron-containing Mal $d 1$ genes was assessed among a set of cultivars chosen for their importance in breeding programs and apple production. In order to find putative associations with allergenicity, the presence of alleles coding for different protein variants was subsequently compared with the degree of allergenicity for a subset of cultivars for which allergenicity data from SPT or DBPCFC tests were available.

\section{Results \\ Diversity of Mal d I genes and deduced proteins}

The observed DNA polymorphisms in the 10 studied cultivars resulted in a total of 46 different Mal $d 1$ sequences over seven genes (Table 1, 2). These sequences were denoted according to the occurrence of 1) DNA polymorphisms in the coding region of the gene leading to different protein variants; 2) polymorphism in the coding region that did not affect the protein sequence (silent mutations), and 3) polymorphism in the intron (Table 1, 2 ). Although the latter two differences are of minor importance with respect to allergenicity, they provided additional landmarks for the development of sequence specific molecular markers.

Mal d 1.01 and -1.02 showed to be highly conserved at the protein level. The related genes coded for only two variants each that both differed in just a single amino acid (pos. $135 \mathrm{~V} / \mathrm{A}$ for Mal d 1.01, pos. $56 \mathrm{~N} / \mathrm{K}$ for Mal d 1.02) and for which the second variant was found only once. The other genes were more variable, coding for three ( $\mathrm{Mal}$ $d$ 1.05) up to six variants (Mal d 1.06C). Mal $d 1.04$ showed to be special in that two (out of the three) sequences contained a stop codon in the coding region 
Table I: Genetic variation in the intron containing Mal $d$ I genes of linkage groups 6 (Mal $d$ I.05) and I3 (Mal d I.0I) among ten apple cultivars.

\begin{tabular}{|c|c|c|c|c|c|c|c|c|c|c|c|c|c|c|}
\hline \multirow[t]{2}{*}{ Iso-allergen } & \multirow[t]{2}{*}{ Variant ${ }^{\mathbf{a}}$} & \multirow[t]{2}{*}{ Sil. mut } & \multirow[t]{2}{*}{ gDNA \# } & \multicolumn{10}{|c|}{ Cultivarc } & \multirow[t]{2}{*}{ GenBank Accessions } \\
\hline & & & & GD & PS & IM & CO & JO & RD & FJ & DS & PM & FS & \\
\hline \multirow[t]{4}{*}{ Mal d I.05 } & 01 & 1 & 1 & $+d$ & + & ++ & ++ & + & + & & + & ++ & + & $\begin{array}{l}\text { AY789245-AY789246, } \\
\text { AY827676-AY827682 }\end{array}$ \\
\hline & 02 & 1 & 2 & & & & & & & & + & & + & AY789247, AY827683 \\
\hline & 02 & 2 & 3 & + & + & & & & & & & & & AY827684-AY827685 \\
\hline & 03 & 1 & 4 & & & & & + & + & ++ & & & & AY827686-AY827688 \\
\hline \multirow[t]{6}{*}{ Mal d I.0I } & 05 & 1 & 1 & & & & & & & & & + & & AY789236 \\
\hline & 05 & 1 & 2 & + & & & & + & & + & & & & AY827639-AY827641 \\
\hline & 05 & 2 & 3 & + & + & ++ & ++ & + & & & ++ & & ++ & AY789238, AY827633-AY827638 \\
\hline & 05 & 3 & 4 & & + & & & & & & & + & & AY789237, AY827642 \\
\hline & 05 & 4 & 5 & & & & & & + & + & & & & AY827643-AY827644 \\
\hline & 09 & 1 & 6 & & & & & & + & & & & & AY827645 \\
\hline
\end{tabular}

\footnotetext{
aVariants refer to different protein sequences. Variant numbers of Mal d I.0I, Mal d I.02 and Mal d I.04 are according to the allergen list (http:// www.allergen.org/Allergen.aspx; Sept 2008), those for Mal d I.05 and Mal d I.06 are according to Gao et al. [15].

bGenome sequences are numbered successively per gene

cGolden Delicious (GD), Priscilla (PS), Ingrid Marie (IM), Cox (CO), Jonathan (JO), Red Delicious (RD), Fuji (FJ), Discovery (DS), Prima(PM) and Fiesta (FS). Note that different accessions of Priscilla seem to exist. The Priscilla used here is a parent of Santana as confirmed by 20 SSR markers (unpublished data), but can not descend from its supposed mother Starking Delicious http://www.hort.purdue.edu/newcrop/pri/coop04.html

d Indicates the presence of an allele in heterozygous $(+)$ or homozygous $(++)$ condition.
}

and were therefore regarded as pseudo alleles ( $p s 1$ and ps2). Interestingly, the pseudo alleles occurred frequently as for seven out of the ten cultivars at least one of the alleles was a pseudo allele whereas cultivars Priscilla and Fuji only contained pseudo alleles of Mal d 1.04 (Table 2).

\section{Allergenicity scores of 14 apple cultivars by skin prick test (SPT)}

Relative SPT responses of 14 apple cultivars are given in Table 3. Fiesta, Delblush, Pinova and Golden Delicious were ranked in the high allergenic group (83-100\%). Priscilla and Santana showed low SPT responses, with wheal areas $30-35 \%$ of that of Golden Delicious. Nine cultivars were intermediate (48-72\%) allergenic. Santana was also identified as low-allergenic in comparison to Golden Delicious in DBPCFC tests [9] and oral provocation tests [10].

\section{General associations from the sequenced cultivars}

From the cultivars used to sequence the intron containing Mal 1 genes and to perform SPT on allergenicity, Golden Delicious was ranked as the highest allergenic cultivar whereas Priscilla was ranked as the lowest (Table 3). This difference was not related to protein variant composition of Mal d 1.01, 1.05, 106B and 1.06C because these cultivars have identical protein variants (Table 2 ). In contrast, both Mal d 1.04 and Mal d 1.06A have different protein variants in Golden Delicious and Priscilla. Mal d 1.04 may contribute to the observed difference in allergenicity between the two cultivars since protein variant 04 is present in Golden Delicious while Priscilla is heterozygous for the two pseudo-alleles $p s 1$ and $p s 2$. Similarly, Mal d 1.06A protein variant -02 was found in Priscilla whereas variants -01 and -03 were found in Golden Delicious. The intermediate cultivars, Jonathan, Prima, and Fuji, have the putatively high allergenic alleles -01 or -03 in single dosage, whereas high allergenic cultivars either have both alleles - 01 and -03, or have - 01 in homozygous state. This suggests that allergenicity might be determined by both the protein variant and the gene dosage of highly allergenic alleles.

\section{Association analysis by pedigrees: from Golden Delicious to Santana}

The identity and origin of genomic alleles and thus protein variants in additional cultivars (not sequenced for Mal d 1) could be traced by developed allele specific SNAP and SSR markers and the use of pedigree information [19] (see Methods). For instance, the deduced flow of protein variants over the pedigree of cultivar Santana is presented in Figure 1. Santana and Priscilla are low allergenic whereas Golden Delicious is high allergenic $[9,10]$. For Mal d 1.01, 1.02 and 1.05 the same protein variants were found for Golden Delicious and Santana. In contrast, Golden Delicious and Santana differ in their protein variant composition of Mal d.1.04, -1.06A and -1.06B (Fig. 1), indicating a possible involvement of these proteins in the observed difference in allergenicity between these cultivars. Santana, like Priscilla, has only pseudo alleles for Mal $d 1.04$ that do not result in protein production, while 
Table 2: Genetic variation in the intron containing Mal d I genes of linkage group 16 among ten apple cultivars.

\begin{tabular}{|c|c|c|c|c|c|c|c|c|c|c|c|c|c|c|}
\hline \multirow[t]{2}{*}{ Iso-allergen } & \multirow[t]{2}{*}{ Variant $^{\mathbf{a}}$} & \multirow[t]{2}{*}{ Sil. mut } & \multirow[t]{2}{*}{ gDNA \# } & \multicolumn{10}{|c|}{ Cultivarc } & \multirow[t]{2}{*}{ GenBank Accns } \\
\hline & & & & GD & PS & IM & co & JO & RD & FJ & DS & PM & FS & \\
\hline \multirow[t]{8}{*}{1.02} & 01 & 1 & 1 & \# & & & \# & \# & & & & \# & \#* & $\begin{array}{l}\text { AY789240-AY789241, AY827646- } \\
\text { AY827648 }\end{array}$ \\
\hline & 01 & 2 & 2 & & & & & & & & & * & & AY789239 \\
\hline & 01 & 3 & 3 & & $\# *$ & $*$ & $*$ & $*$ & $*$ & $*$ & & & & AY827649-AY827654 \\
\hline & 01 & 4 & 4 & $*$ & & & & & & \# & & & & AY827655-AY827656 \\
\hline & 01 & 5 & 5 & & & \# & & & & & & & & AY827657 \\
\hline & 01 & 6 & 6 & & & & & & \# & & & & & $\overline{A Y 827658}$ \\
\hline & 01 & 7 & 7 & & & & & & & & + & & & AY827659 \\
\hline & 09 & 1 & 8 & & & & & & & & + & & & $\overline{\text { AY } 827660}$ \\
\hline \multirow[t]{7}{*}{1.04} & 04 & 1 & 1 & & & & & & & & & $*$ & & AY789242 \\
\hline & 04 & 2 & 2 & $\#^{\mathrm{e}}$ & & & $\#$ & $\#$ & $\#$ & & & \# & $\#^{*}$ & $\begin{array}{l}\overline{\text { AY789243 }}-\mathrm{AY} 789244, \text { AY82766I- } \\
\text { AY827664 }\end{array}$ \\
\hline & 05 & I & 3 & & & & & & & & + & & & $\overline{\mathrm{AY} 827665}$ \\
\hline & 06 & 1 & 4 & & & \# & & & & & & & & AY827666 \\
\hline & 07 & 1 & 5 & & & & & & & & + & & & AY827667 \\
\hline & psI & I & 6 & & \#* & & & $*$ & $*$ & $*$ & & & & AY827668-AY82767I \\
\hline & ps2 & 1 & 7 & $*$ & & $*$ & $*$ & & & \# & & & & $\overline{\text { AY } 827672}-\overline{A Y 827675}$ \\
\hline \multirow[t]{7}{*}{$1.06 \mathrm{~A}$} & 01 & I & $1-10$ & \# & & & \# & \# & & & & & $\#^{*}$ & AY789249, AY827689-AY827691 \\
\hline & 01 & 1 & $2-11$ & & & & & & & & & \# & & $\overline{\text { AY789250 }}$ \\
\hline & 02 & i & $3-16$ & & & & & & & & & $*$ & & AY789248 \\
\hline & 02 & 2 & $4-6$ & & $\#^{*}$ & $*$ & $*$ & $*$ & $*$ & $*$ & & & & AY827692-AY827697 \\
\hline & 02 & 3 & $5-10$ & & & \# & & & \# & & & & & AY827698-AY827699 \\
\hline & 02 & 4 & $6-7$ & & & & & & & & + & & & AY 827700 \\
\hline & 03 & 1 & $7-7$ & $*$ & & & & & & \# & + & & & AY827701-AY827703 \\
\hline \multirow[t]{7}{*}{$1.06 \mathrm{~B}$} & 01 & I & 1 & \# & \# & & \# & \# & & & & & $\#^{*}$ & AY789251, AY827704-AY827707 \\
\hline & 02 & 1 & 2 & $*$ & $*$ & & & $*$ & $*$ & $\# *$ & & \# & & $\overline{\mathrm{AY} 789252}, \overline{\mathrm{AY} 827708}-\overline{\mathrm{AY} 827712}$ \\
\hline & 03 & I & 3 & & & & & & \# & & & $*$ & & AY789253, AY827713 \\
\hline & 03 & 2 & 4 & & & \# & & & & & & & & AY827714 \\
\hline & 04 & 1 & 5 & & & $*$ & $*$ & & & & & & & AY827715-AY827716 \\
\hline & 05 & I & 6 & & & & & & & & + & & & $\overline{\text { AY827717 }}$ \\
\hline & 05 & 2 & 7 & & & & & & & & + & & & AY827718 \\
\hline \multirow[t]{6}{*}{$1.06 \mathrm{C}$} & 01 & I & 1 & \# & \# & & \# & \# & & & & & $\#^{*}$ & AY789254, AY827719-AY8277222 \\
\hline & $02 \mathrm{~g}$ & 1 & 2 & & & & & & & & & $*$ & & AY789255 \\
\hline & $03 \mathrm{~g}$ & I & 3 & $*$ & $*$ & & & * & $*$ & \#* & + & $\#$ & & AY789256, AY827723-AY827725 \\
\hline & 04 & I & 4 & & & \# & & & & & + & & & AY827726 \\
\hline & 05 & 1 & 5 & & & & & & $\#$ & & & & & AY 827727 \\
\hline & 06 & 1 & 6 & & & $*$ & $*$ & & & & & & & AY 827728 \\
\hline
\end{tabular}

aVariant numbers of are according to the allergen list (see Table I), those for Mal d I.05 and Mal d I.06 are according to Gao et al. [I5].

b, c, d as in Table I

e \# and * For LG 16, alleles that have the same symbol are in coupling phase with each other. This information was obtained by their co-segregation patterns in mapping progenies (Prima $\times$ Fiesta and Jonathan $\times$ Prima [15], and over pedigrees (Fiesta $=$ Cox $\times$ Idared [= Jonathan $\times$ Wagner Apfel]); Ingrid Marie $=$ Cox $\times$ open pollinated and Fuji $=$ Ralls Janet $\times$ Delicious; Red Delicious is a colour mutant of Delicious.

fps I and ps 2 of Mal d I.04 refer to pseudo-alleles.

$\mathrm{g}$ The allele specific markers for these alleles were derived from Table 3 of Gao et al. 2005 [I5] whereby we took into account that their marker for Mal d I.06C02 actually amplifies Mal d I.06C03 and visa versa, thus harmonizing an inconsistency between their tables 2 and 3 in the assignment of allele and marker names to the AY789255 and AY789255 sequences. 
Table 3: SPT responses of apple cultivars relative to Golden Delicious (in \%) for 4 experiments.

\begin{tabular}{lccccc}
\hline Cultivar & \multicolumn{2}{l}{ Experiment ${ }^{\mathrm{a}}$} & \multicolumn{3}{l}{ Average } \\
\cline { 2 - 5 } & I & II & III & IV & \\
\cline { 2 - 5 } & & & & 30 & 30 \\
Priscilla & 34 & & 38 & 30 & 34 \\
Santana & & & & 48 & 48 \\
Jonathan & 39 & 62 & & & 51 \\
Ecolette & & & & 61 & 61 \\
Prima & 67 & & 52 & & 60 \\
Elstar & 70 & 69 & 48 & & 62 \\
Fuji & 65 & & 62 & & 63 \\
Gala & 67 & & & & 67 \\
Elize Roblos & 72 & & & & 72 \\
Bellida & 67 & & & 99 & 83 \\
Fiesta & 87 & & & & 87 \\
Delblush Tentation & 89 & & & & 89 \\
Pinova & $100^{\mathrm{b}}$ & 100 & 100 & 100 & 100 \\
Golden Delicious & & & & & \\
\hline
\end{tabular}

a Data for the first three experiments were derived from the original data from three experiments of Bolhaar et al. [9] on respectively cultivar screening, intra-cultivar variation and storage, of which we used only the data of patients with mild symptoms. The forth experiment came from a new cultivar screening experiment. b The underlying HEP values for Golden Delicious for the four experiments were respectively $0.54,0.45,0.63$ and 0.69 .
Golden Delicious has one functional allele. The Mal d 1.06A02 variant of Santana is not present in Golden Delicious.

\section{Associations for Mal d I.04 and -I.06A}

Similarly to Santana, pedigree information and sequence specific markers were used to assess the putative protein variant composition for other additional cultivars for which we have SPT response data. This allowed a further validation of the association of the Mal d 1.04 and 1.06A with allergenicity in a total of 14 cultivars (Table 4). Cultivars Delblush and Pinova evoked an SPT response that was similar to that of Golden Delicious and also had the same variant compositions as Golden Delicious for Mal d 1.04 and Mal d 1.06A, namely variant 04 for Mal d 1.04 (coded for by a single allele) and the two variants 01 and 03 for Mal d 1.06. The remaining five cultivars evoking an intermediate allergenic response also had a similar variant composition as the previously identified intermediate cultivars, namely variants 02 and 03 for Mal d 1.06A, and variant 04 of Mal d 1.04 (coded for by a single allele dosage), except for Prima, that has two alleles coding for Mal d 1.0404 and Fuji that contains both pseudo alleles. The other intron containing genes did not show any association (data not shown).

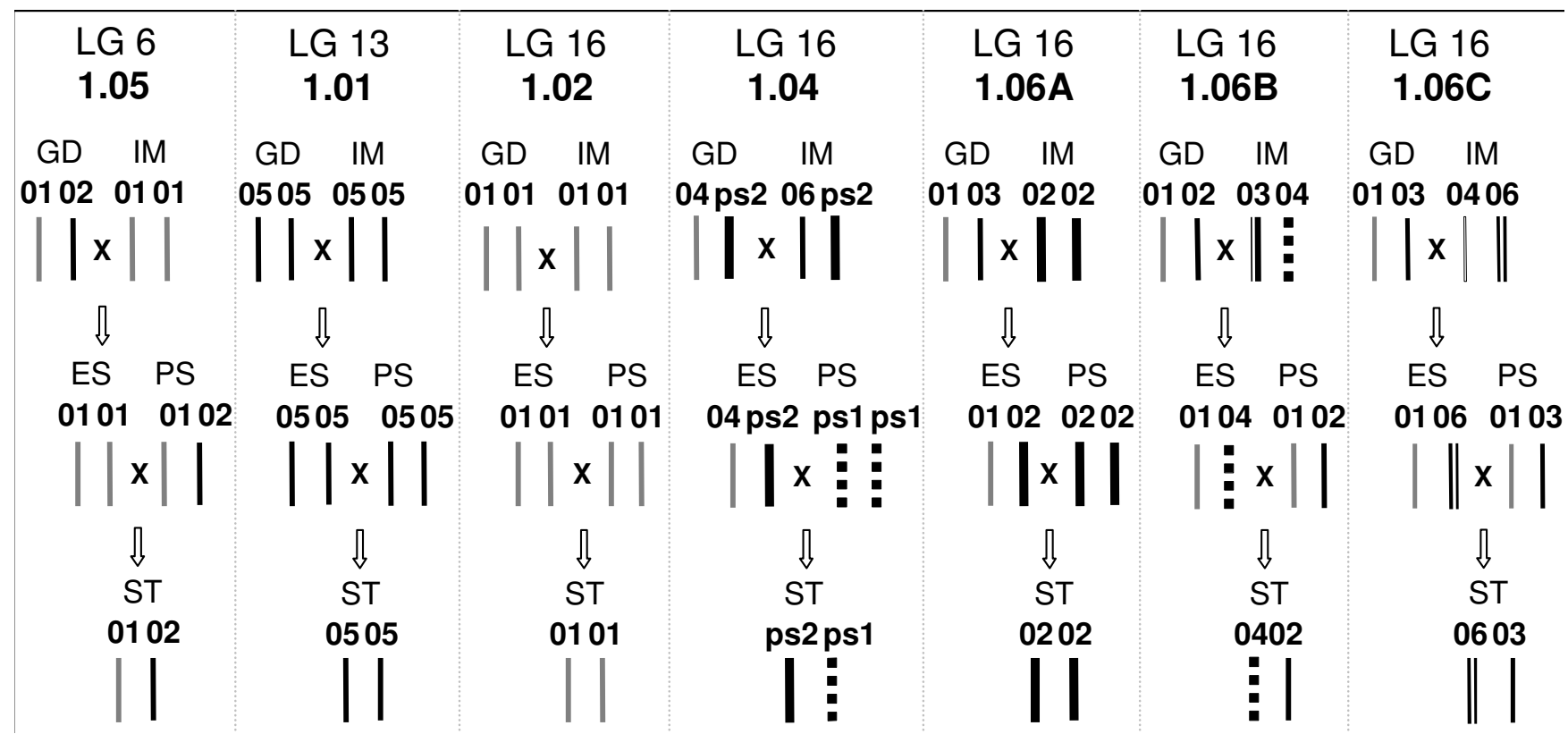

Figure I

Flow of putative protein variants over the pedigree of Santana for seven Mal d I genes. Abbreviated cultivar names are according to Table I. GD is high allergenic whereas PS and ST are low allergenic $[9,10]$. 
Table 4: SPT responses of $\mathrm{I} 4$ apple cultivars and the putative protein constitutions of these cultivars for two Mal $d \mathrm{I}$ iso-allergens.

\begin{tabular}{|c|c|c|c|c|c|}
\hline \multirow{2}{*}{$\begin{array}{l}\text { Cultivara }^{\mathrm{a}} \\
\text { Priscilla }\end{array}$} & \multirow{2}{*}{$\begin{array}{l}\text { SPT-response }^{\mathbf{b}} \\
30\end{array}$} & \multicolumn{2}{|c|}{ Mal d I.04 } & \multicolumn{2}{|c|}{ Mal d I.06A } \\
\hline & & psI & ps2 & 02 & 02 \\
\hline Santana & 35 & psI & psI & 02 & 02 \\
\hline Jonathan & 48 & psI & 04 & 01 & 02 \\
\hline Ecolette & 51 & ps2 & 04 & 01 & 02 \\
\hline Prima & 61 & 04 & 04 & 01 & 02 \\
\hline Elstar & 61 & ps2 & 04 & 01 & 02 \\
\hline Fuji & 61 & psI & ps2 & $\underline{03}$ & 02 \\
\hline Gala & 64 & $\mathrm{ps} 1 / \mathrm{ps} 2$ & 04 & 01 & 02 \\
\hline Elise & 67 & ps2 & 04 & 01 & 02 \\
\hline Bellida & 72 & 04 & 04 & 01 & 01 \\
\hline Fiesta & 83 & psI & $04^{3}$ & 01 & 01 \\
\hline Delblush & 87 & ps2 & 04 & 01 & $\underline{03}$ \\
\hline Pinova & 89 & 04 & ps2 & 01 & $\underline{03}$ \\
\hline Golden Delicious & 100 & ps2 & 04 & 01 & $\underline{03}$ \\
\hline
\end{tabular}

a: Cultivars in bold were sequenced for their intron containing Mal d I genes

b: In \% relative to Golden Delicious.

\section{Discussion}

Birch pollen induced oral allergy for apple has been the subject in a considerable number of studies. One of the prominent results has been the presence of cultivar-specific differences in allergenicity. Unfortunately, evidence regarding the causes of cultivar-specific allergenicity is still lacking. One of the knowledge gaps concerned the number and identity of Mal $d 1$ genes and the amount of variation within these genes. Recently, Gao et al. [15] have shown that Mal $d 1$ genes are members of a large gene family by identifying 18 different loci that are located in three clusters. Based on sequence identity, these 18 genes could be subdivided into intron containing and intronless genes. In order to create a basis for a better understanding of the genetics of Mal $d 1$ genes and their impact on allergenicity, we have studied the allelic diversity of the intron containing genes in 10 cultivars that are often used in breeding. Development of sequence specific markers and pedigree information enabled the assessment of putative Mal $d 1$ constitutions of other cultivars. Using this information, we assessed the different Mal d 1 isoforms that cultivars are able to produce and found associations between their putative protein constitutions and SPTresponses.

\section{Allelic diversity and validity of database sequences}

Cloning and sequencing of the seven intron-containing Mal d 1 genes in 10 cultivars revealed 46 different alleles that coded for 25 different Mal d 1 isoforms. The variation per gene varied with regard to the number of alleles and deduced proteins. Mal d 1.01 and Mal d 1.02 were diverse at the gDNA level but conserved at the protein level. For both genes only two protein variants were found, of which the second variant, differing in one amino acid only, was found in just a single cultivar. For Mal d 1.04,
Mal $d 1.05$ and the three Mal d 1.06 genes, gDNAs often coded for different proteins and these genes were therefore more variable at the protein level.

Because the examined cultivars are important in the breeding of many modern apple varieties, the set of alleles found in this study likely represents a considerable part of the total variation present in intron containing Mal $d 1$ genes of common apple varieties.

Although other Mal $d 1$ sequences are known from public databases, we suspect that many of these sequences may be artefacts derived through strand switching and PCR mutations. The problem associated with PCR amplification of a group of closely related sequences, such as the Mal $d 1$ gene family, is that besides PCR induced single base pair mutations, in vitro strand switching or reannealing of incompletely amplified fragments can lead to artefacts as was exemplified by Schenk et al. [20] for birch Bet v1 sequences. For instance, for Mal d 1.01 one of the most studied Mal $d 1$ genes, over 13 DNA sequences from previous studies are known from public databases (Table 5) indicating the presence of 9 putative protein isoforms. We know Mal d 1.01 is a single locus gene with maximum two alleles present in a cultivar [15], but four sequences from Golden Delicious can be found in databases. From these, only sequence accession AF124830 was identical to one of our two sequences (Mal d 1.0105.01b). The other sequences may be due to artefacts. Firstly, accession AF126402 had one SNP at position $11(\mathrm{G} \rightarrow \mathrm{A})$ compared to $\underline{\mathrm{AF} 124830}$, which is due to the cloning primer used. Similarly, sequences from a number of other cultivars showed this $11 \mathrm{~A}$ mutation too. In our study, the cloning primers used were positioned in the 5 '-untranslated region thus avoiding this problem. Secondly, Accession 
Table 5: SNPs among Mal $d$ I.0I sequences as found in databases.

\begin{tabular}{|c|c|c|c|c|c|c|c|c|c|c|c|c|c|c|c|c|c|c|c|c|c|c|c|c|c|}
\hline Allele & Cultivar $^{b}$ & Nuc & leotide & posit & ion in & coding & seque & nces $^{c}$ & & & & & & & & & & & & & & & & & \\
\hline \multirow[t]{3}{*}{$\left(\right.$ Genbank accession no) ${ }^{\mathrm{a}}$} & & 11 & 21 & 29 & 49 & 75 & 84 & 222 & 294 & 334 & 360 & 364 & 404 & 405 & 408 & 413 & 419 & 420 & 435 & 453 & 456 & 458 & 465 & 468 & 471 \\
\hline & & \multicolumn{24}{|c|}{ Consensus nucleotide } \\
\hline & & G & G & $\mathrm{T}$ & $\mathrm{T}$ & $\mathrm{T}$ & C & G & A & $\mathrm{T}$ & C & A & C & $\mathrm{T}$ & A & A & C & c & G & $\mathrm{T}$ & G & A & C & C & A \\
\hline Mal d I.0I0I ( $\underline{X 3672})$ & GS & $\underline{A}$ & & & & & & & & & & & $\mathrm{~T}$ & & & & & & & & & & & & \\
\hline Mal d I.0102 (Z48969) & GD & $\underline{A}$ & $\underline{A}$ & & & & & & & $\underline{G}$ & & $\underline{c}$ & $\mathrm{~T}$ & $\underline{c}$ & & & $\underline{G}$ & $\underline{I}$ & & $\underline{c}$ & & $\underline{G}$ & $\underline{G}$ & $\underline{I}$ & $\underline{c}$ \\
\hline Mal d I.0I03 (AFI24823) & $\mathrm{JB}$ & $\underline{A}$ & & & & & & A & & & & & & & & & & & A & & A & $G$ & & & \\
\hline Mal d I.0I04 (AFI24829) & $J G$ & $\underline{A}$ & & $\underline{A}$ & $\underline{C}$ & $\underline{C}$ & $\underline{I}$ & & & & $\mathrm{~T}$ & & & & & & & & & & & & & & \\
\hline $\begin{array}{l}\text { Mal d I.0105.0I } \\
\text { (AFI24830, AY428579) }\end{array}$ & $\begin{array}{l}\text { GD, GA, PM, GD, } \\
\text { JO, FJ }\end{array}$ & & & & & & & & & & $\mathbf{T}$ & & & & & & & & & & & & & & \\
\hline Mal d I.0105.02 & $\begin{array}{l}\text { PM, FS, GD, PS, } \\
\text { IM, JO, CO, DS }\end{array}$ & & & & & & & $\mathbf{A}$ & & & & & & & & & & & A & & & & & & \\
\hline Mal d I.0I05.03 & PM, PS & & & & & & & & & & & & & & & & & & & & & & & & \\
\hline Mal d I.0105.04 & RD, FJ & & & & & & & A & & & & & & & & & & & & & & & & & \\
\hline Mal d I.0I06 (AFI2483I) & $\mathrm{GL}$ & & & & & & & & C & & & & & & & & & & & & & & & & \\
\hline Mal d I.0I07 (AFI24832) & GA & $\underline{A}$ & & $\underline{A}$ & & $\underline{c}$ & $I$ & A & & & & & & & $\underline{c}$ & $\underline{c}$ & & $\underline{I}$ & & $\underline{c}$ & & & & & \\
\hline Mal d I.0I08 (AFI26402) & GD & $\underline{A}$ & & & & & & & & & $\mathrm{~T}$ & & & & & & & & & & & & & & \\
\hline Mal d I.0109 (AY026910) & GD-seedling, RD & & & & & & & & & & & & $\mathbf{T}$ & & & & & & & & & & & & \\
\hline
\end{tabular}

\section{Mal d I.02-CONSd}

A $\quad G \quad A \quad C \quad C \quad$ T $\quad$ G

G TC

C $A$

C T

A

C

G

$\mathrm{C} / \mathrm{T} \quad \mathrm{G}$

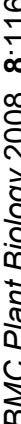

a Alleles in bold are confirmed by our own sequences (see Table ). Numbers in brackets indicate Genbank accessions of previous sequences.

b Cultivar abbreviations additional to those in Table 2: GA-Gala, JB-Jamba, GL-Gloster, GD-seedling: seedling from Golden Delicious. Cultivar names in bold indicate material from this study.

$\infty$ cPosition refers to the coding sequence and is presented vertically. SNP nucleotides given in bold are our own observations. SNPs in italic are identified errors after cross checking.

dMal d 1.02 consensus SNPs compared with Mal d I.01. 
Z48969 [21] that was classified as Mal d 1c [10] is quite similar to Mal d 1.01, while the SNPs found are unique to three other Mal $d 1$ genes. This may be due to an artefact from strand switching during PCR which could explain why we, like other researchers could not retrieve this sequence from Golden Delicious [[10,17]; this study]. Similarly, the first 84 nucleotides of $\underline{\mathrm{AF} 124829}$ and AF124832 match to Mal 1.02 (typical SNPs are shown at the bottom of Table 5), while the remaining sequence matches to Mal d 1.01 making these accessions also putative erroneous sequences due to strand switching. Therefore, the actual number of Mal d 1.01 variants present among apple cultivars is probably not as high as nine, because at least five of them are likely PCR artefacts. Two protein variants (1.0105 and 1.0109) of Mal d 1.01 could be confirmed in this study. Variants Mal d 1.0104, 1.0107 and 1.0108 are likely artefacts of 1.0105 whereas 1.0101 and 1.0102 are likely artefacts of 1.0109 .

The occurrence of PCR recombination and mutations in sequences from gene families warrants scrutinised assessment of sequences. The use of two independent PCR-cloning steps for each cultivar may effectively filter out most of these erroneous sequences before database donation since the probability of isolating identical artefacts in independent PCRs is low [20]. Sequence specific markers may be used to validate newly found isoforms that have passed this first sifting. Many of the sequences found in this study were either confirmed by identical sequences retrieved from the other cultivars used or by identical sequences previously donated in the databases as well as through the use of sequence specific markers [[15], this study].

\section{Cultivar specific allergenicity and its relation to quantitative and qualitative differences in Mal d I}

Levels of total Mal d 1 protein can not fully explain allergenicity of cultivars, indicating that other factors are involved as well. For instance, Son et al. [10] found a fourfold higher level of Mal d 1 protein in Granny Smith compared to Gloster. Although this suggests a correlation between total amount and allergenicity, this relation was contradicted by their results on Golden Delicious and Granny Smith, which cultivars were similar allergenic despite of a threefold difference in total Mal d 1 content. Furthermore, it was demonstrated that different Mal d 1 isoforms [10], as well as mutants of specific isoforms [13], have different binding affinities to IgE indicating that the relative Mal d 1 protein composition as well as the presence of specific alleles may have a significant effect on allergenicity.

This research is the first to show an association between the genetic Mal $d 1$ constitution of apple cultivars and birch pollen related allergenicity. If the allergenicity is a matter of the variants of a single gene, then Mal d 1.06A will be the most outstanding candidate. In case of the involvement of multiple genes, also Mal d 1.04 may play a role. A putative involvement of the intronless genes can not yet be excluded, as their allelic variation has not yet been surveyed. Such a survey will be a challenge considering the high sequence similarity among alleles of different loci, which can be over 98\% [15]. With regard to Mal d 1.04, two of the sequenced cultivars showed variant compositions for Mal d 1.04 that did not exactly fit with the relative SPT data found. Prima has the functional allele of Mal d 1.04 in duplex but has an intermediate allergenicity, whereas Fuji is the only intermediate-allergenic cultivar that had two pseudo-alleles for Mal d 1.04 (Table 2). This might indicate that Mal d 1.04 does not show dosage allele effects and cannot explain allergenicity without considering other factors. Alternatively, these two exceptions infer variant 03 of Mal d 1.06A to be more allergenic than variant 01 , in which case the stronger effect of 03 in Fuji is counteracted by the absence of a functional allele for Mal d 1.04. Similarly, the milder effect of variant 01 of Prima is then compensated by the double dosage of a functional Mal d 1.04 allele. A stronger effect of variant 03 fits with the tendency of higher responses of the three heterozygous 01/03 cultivars compared to the two 01 homozygous cultivars.

The above described associations could be found due to the presence of allelic variation among the examined apple cultivars and due to performing a complexity reduction of the human variation by only analysing patients with mild SPT responses, thus reducing the effect of variation among humans for sensitivity to different allergens. Studies with larger patient sizes may probably benefit from further grouping to also account for genetically determined human variation in sensitivity to different (iso) allergen variants. Such grouping has probably to be based on allergy responses as no knowledge exists on the involved human genes neither on their allelic composition.

The finding that allergenicity depends on the presence and amount of some specific Mal d 1 isoforms is highly relevant for diagnostics tests and immunotherapy, and justifies additional research on a larger number of apple cultivars as well as atopic individuals. Since the first Mal $d$ 2 and Mal $d 4$ genes have also been recently mapped [22] and the mapping of additional genes of these allergens is in progress, it will become possible to also investigate the effects of allelic composition of these Mal d allergens on the allergenicity of cultivars by association studies.

\section{Location of amino acid polymorphism in a 3D structure model}

For Mal d 1.06A, high-allergenic cultivars have two putative genotypes, homozygous variant 01 or heterozygous 
variant 01 together with variant 03 , whereas low-allergenic cultivars are homozygous for variant 02 . The intermediate-allergenic cultivars contained the low allergenic variant 02 in combination with one of the high allergenic variants 01 or 03 .

The three Mal d 1.06A variants differ at two amino acids: $13 \mathrm{~V} / \mathrm{I}$ and 135V/A. Considering the three dimensional structure model of Mal d 1 [23], the first polymorphism is located in the first loop between the $\beta 1$-strand and the $\alpha 1$ helix, the second is located in the $\alpha 3$-helix structure motif. The amino acid changes are all between hydrophobic amino acids but they have different side chains that may have an effect on the 3D structure of the protein and thus on epitope conformation.

\section{Expression of Mal d I genes in fruit}

For specific Mal d 1 genes to be involved in allergenicity, expression in apple fruit is a prerequisite. Until now, mRNA expression for five genes was observed in mature fruit through both $\operatorname{rtPCR}[16,24]$ and EST sequences (unpublished), representing two genes (Mal $d 1.01$ and $03 E$ ) on LG 13 and three genes (Mal d 1.02, -06A and $06 B$ ) on LG 16., whereas mRNA based EST sequences of Mal $d 1.04$ were only found in mature leaves. Because the number of rtPCR studies on and EST sequences derived from fruit is still limited and usually only assessed at a single time moment, definitive mRNA based conclusions regarding Mal d 1.04 expression in fruit can not yet be made. Recently obtained proof for its expression in the epidermis of fruit [24] is not conclusive as the primers used can probably also amplify mRNA of Mal $d 1.05$ and Mal $d 1.06 B$. From ESTs identified in cDNA libraries of ripe Gala fruit, tissue specific expression patterns were found. Mal d 1.01 and Mal d 1.02 ESTs were found in both skin and cortex, while Mal d 1.06A, 1.06B and 1.03E ESTs were only found in the skin of apple fruit. At this moment, there is evidence for the presence of two Mal d 1 proteins in apple fruit $[17,18]$, the majority of Mal d 1 protein is Mal d 1.02 ( Mal d 1b) and a minor part is Mal d 1.06A [15]. Interestingly, both genes are located on linkage group 16 where also Mal $d 1.04$ is located. These mRNA and protein data thus allow Mal d 1.06A to be involved in differences in allergenicity among cultivars. The current lack of support for the presence of Mal d 1.04 in fruit might indicate that the observed association is coincidental, but may as well be due to lack of extensive expression studies.

\section{Genotyping for Mal d I haplotypes}

The Mal $d 1$ genes in LG 16 are tightly linked to each other [15]. This tight linkage can simplify the genotyping of additional cultivars, at least if their pedigree and the linkage phase of their parental alleles are known. In these cases, genotyping can be performed by a single represent- ative, multi-allelic marker such as the Mal d 1.06A SSR marker. As linkage phases of the Mal $d 1$ genes of LG 16 are known for all 10 cultivars of our reference set but Discovery (Table 2), this simple and efficient approach was performed in this study for certain cultivars (Figure. 1).

\section{Conclusion}

We have shown that differences in allergenicity among apple cultivars are associated with the allelic composition of two specific genes, Mal $d 1.04$ and Mal d 1.06A, which are both located on linkage 16 of Malus domestica. Furthermore, allele dosage effects are found relevant for Mal $d$ 1.06A. Our findings indicate the need to reconsider the relevance of merely assessing total amounts of Mal d 1 protein in allergy research and diagnostic tests and warrant further research on the association of specific Mal d 1 isoforms and allergenicity among a larger group of cultivars and allergy sufferers.

\section{Methods}

\section{Cultivars for cloning and sequencing}

Eight cultivars were used for cloning and sequencing of Mal $d 1$ isoallergen genes: Golden Delicious (GD), Priscilla (PS), Ingrid Marie (IM), Cox (CO), Jonathan (JO), Red Delicious (RD), Fuji (FJ) and Discovery (DS). Including the two parental cultivars Prima (PM) and Fiesta (FS) used in our previous mapping study [15], a total of ten cultivars were under investigation. They were chosen for three reasons: (1) GD, JO, CO and RD are founders in many breeding programmes world wide, and RD, GD and FJ are main cultivars for apple production in the world; (2) GD, IM and PS are members in the pedigree from GD (hyper-allergenic) to Santana $(\mathrm{ST})=[\mathrm{PS} \times$ Elstar $(=\mathrm{GD} \times$ IM)] a hypo-allergenic cultivar; (3) JO, DS, PM and FS are the parents of three mapping progenies.

\section{Genomic cloning and sequencing of intron-containing Mal d I genes}

For each cultivar, all seven intron-containing Mal d 1 genes were cloned and sequenced: Mal $d 1.05$ of linkage group (LG) 6; Mal d 1.01 of LG 13; and Mal d 1.02, -1.04, $-1.06 A,-1.06 B,-1.06 C$ of LG 16 . Six primer pairs were used for cloning [15], of which those for Mal $d 1.04$ and Mal 1.05 were newly designed (Table 6). The PCR amplification, cloning and sequencing procedures were described previously $[15,22]$. For all 10 cultivars, eight to ten clones for each gene were sequenced in both directions. Next, sequences were aligned and putative Single Nucleotide Polymorphisms (SNPs) were identified using the Seqman program (DNAstar, Madison, WI). The coding sequences were deduced and translated into amino acid sequences for alignments and assessment of protein variant with the GeneDoc program http://www.psc.edu/ biomed/genedoc. New protein variants or gDNA alleles were named according to Gao et al. $[15,22]$, following a 
modification of the allergen nomenclature guidelines [25].

\section{Cultivars for association studies}

Allergenicity data were available for 6 out of the 10 cultivars for which we assessed allelic diversity [9]. Besides these six cultivars, eight additional cultivars were included in the association study. For these eight cultivars allergenicity data were available [9] and their allelic constitutions of the intron-containing Mal $d 1$ genes could be assessed by their pedigree relationships to the set of 10 sequenced cultivars.

For this, sequence-specific SNAP markers [23,27] were developed (Table 7) and applied to these cultivars. Primer design and test procedures were described previously $[15,27]$. Primers for the Mal d 1.06A SSR marker [15] were redesigned according to new sequence data obtained. The PCR reaction mixture for this SSR marker consisted of $2 \mu \mathrm{l}$ $10 \times$ buffer, $1.2 \mu \mathrm{l} \mathrm{MgCl}_{2}(25 \mathrm{mM}), 0.4 \mu \mathrm{ldNTPs}(10 \mathrm{mM})$, $1 \mu \mathrm{l}$ of each primer $(2 \mu \mathrm{M}), 0.06 \mu \mathrm{l}$ Taq polymerase $(5 \mathrm{U} /$ $\mu \mathrm{l})$ and $1 \mu \mathrm{l}$ DNA $(10 \mathrm{ng} / \mu \mathrm{l})$ in a total volume of $20 \mu \mathrm{l}$. After an initial denaturation at $94^{\circ} \mathrm{C}$ for $2.5 \mathrm{~min}$, the amplification was carried out for 34 cycles at $94^{\circ} \mathrm{C}$ for 30 $\mathrm{s}, 60^{\circ} \mathrm{C}$ for $30 \mathrm{~s}$ and $72^{\circ} \mathrm{C}$ for $1 \mathrm{~min}$, and a final extension at $72^{\circ} \mathrm{C}$ for $5 \mathrm{~min}$. PCR products were analysed on an $\mathrm{ABI}$ 377 (Applied Biosystems, Foster City, Calif.).

Using the SNAP makers, the pedigree structures allowed us to follow the flow of the Mal $d 1$ alleles over generations by applying the Identity by Descent principle in the genotyping of cultivars [19]. In total 14 cultivars were thus available for association of protein variant composition with SPT responses.

\section{Allergenicity data}

In this study, Skin Prick Test (SPT) responses were used to evaluate allergenicity. The SPT procedure and the history of the patients have been described previously [9]. In short, patients were recruited from the outpatient clinic of the department of Dermatology/Allergology of the UMCU. They all had birch pollinosis manifesting with rhinoconjunctivitis during the birch pollen season (April and May), as well as a positive SPT to fresh apple of at least half the diameter of the positive histamine control. All patients had a typical history of apple allergy, with oral allergy syndrome (OAS) symptoms like itching and mild swelling of the mouth, throat and sometimes rhinoconjuctivitis after eating an apple. SPT were performed on the flexor surface of the forearm using the prick-to-prick-technique according to Dreborg $[28,29]$.

Histamine dihydrochloride $(10 \mathrm{mg} / \mathrm{ml})$ was used as a positive control, and the glycerol diluents of the SPTextracts were used as negative control (ALK-ABELLO, Nieuwegein, The Netherlands). The wheal reaction (a small, itching elevation of the skin, as from the bite of an insect) was marked and transferred with transparent adhesive tape to a record sheet. The skin wheal areas were measured by computer scanning [30]. SPT responses for each cultivar were standardized by dividing the original wheal area of the prick by that obtained from the reference cultivar for high allergenicity Golden Delicious and multiplied by 100. Data have been derived from four experiments, three of which had been published previously [9]. For each experiment we used only a fraction of the data, this is only the data of patients with mild symptoms as preliminary experiments indicated that Mal $\mathrm{d} 1$ is the major allergen to these patients, while other Mal d proteins seem to be major allergens to patients displaying more severe symptoms (Van de Weg, unpublished). Consequently, only $25 \%-50 \%$ of the patients of the previous experiments [9] and only $50 \%$ of the patients ( 4 out of 8 ) of the forth, new experiment were included. Finally, 11 different patients were involved. In order to combine data from these different experiments, responses of cultivars

Table 6: Cloning primers and PCR conditions.

\begin{tabular}{|c|c|c|c|c|}
\hline Gene & Primers $^{a}$ & Pfub Tm/cycles & Taq Tm/cycles & Reference sequence \\
\hline Mal d I.0I & $\begin{array}{l}\text { F: ATCTCCAACACAATACTCTCAAC } \\
\text { R: AAAGCCACACAACCTTCGAC }\end{array}$ & $58 / 25$ & $60 / 2$ & AY789236 \\
\hline Mald I.02 & $\begin{array}{l}\text { F: CATCCTTGGTAGTTGCTTTC } \\
\text { R: ACCATAGAAACATATTAATTTAGT }\end{array}$ & $52 / 25$ & $54 / 2$ & AY789239 \\
\hline Mald I.04 & $\begin{array}{l}\text { F: CGTAGTTGGACAAGTGTCTTAGT } \\
\text { R: AGGGTAACACACAAATTACATG }\end{array}$ & $58 / 30$ & $60 / 2$ & AY789242 \\
\hline Mald 1.05 & $\begin{array}{l}\text { F: AGTTCATCATGGGTGTTTTC } \\
\text { R: GGTAACACACAAATTACAAATATGC }\end{array}$ & $53 / 30$ & $55 / 2$ & AY789245 \\
\hline Mal d I.06A-C & $\begin{array}{l}\text { F: CATGGGTGTCCTCACATACGAAAC } \\
\text { R: TTAGTTGTAGGCATCAGGATTG }\end{array}$ & $55 / 25$ & $57 / 2$ & AY789248 \\
\hline Mald I.06C & $\begin{array}{l}\text { F: ATGGGTGTCCTCACATACGAAACT } \\
\text { R: TTAGTTGTAGGCATCAGGATTGGCCACAAGGTG }\end{array}$ & $62 / 30$ & $64 / 2$ & AY789255 \\
\hline
\end{tabular}

aPrimers for Mal d I.04 and Mal d I.05 are new, others have been adopted from Gao et al. [I5].

b The PCR was performed in two steps starting with Pfu polymerase and finishing with super Taq [15,22]. 
Table 7: Description of nine sequence-specific SNAP markers and one SSR marker used for the genotyping of cultivars (in bold: SNP, underlined are deliberate introduced SNP to increase specificity).

\begin{tabular}{|c|c|c|c|c|c|}
\hline Marker name ${ }^{a}$ & Primers 5'-3' & SNPs detected & Product (nt) & $\operatorname{Tm}^{c}$ & Cycles $^{d}$ \\
\hline Mal d I.010502 & $\begin{array}{l}\text { F: TGAAGCACAGGATTGACGCA } \\
\text { R: CCACACAACCTTCGACTCA }\end{array}$ & $390 \mathrm{~A}$ & 346 & 56 & 35 \\
\hline Mal d I.0I050I & $\begin{array}{l}\text { F: AGCTGAAATCCTTGAACGAA } \\
\text { R: CAATGTTTCCCTTGGTGAGA }\end{array}$ & $-528 \mathrm{~T}$ & 426 & $55 / 53$ & $10 / 30$ \\
\hline Mal d I.010503 & $\begin{array}{l}\text { F: TGAAGCACAGGATTGACACACG } \\
\text { R: CAATGTTTCCCTTGGTGTCG }\end{array}$ & $390 G 528 C$ & 177 & $57 / 55$ & $10 / 30$ \\
\hline Mal d I.020I-I & $\begin{array}{l}\text { F: TCACTTTTGGTGAAGGTCIGG } \\
\text { R: AGGCGTATGAGTAGTTTACC }\end{array}$ & $-402 \mathrm{G}$ & 252 & 57 & 35 \\
\hline Mal d I.020I-4 & $\begin{array}{l}\text { F: ATTATTTAGATGGTTTCGCTAT } \\
\text { R: TATGCGTCGGGGTGTCCCTAG }\end{array}$ & 227T 624C & 439 & 55 & 35 \\
\hline Mal d I.020I-3 & $\begin{array}{l}\text { F: GCCCTGGAACCATCAAGIAG } \\
\text { R: GGCTGCCTGTGAGACAACT G }\end{array}$ & I65G, I68G 342C & 213 & 61 & 35 \\
\hline Mal d I.04-6/7 & $\begin{array}{l}\text { F: CATCCCGAAGATTGCTCCG } \\
\text { R: CCTTAGCATGGTAGTGGC品G }\end{array}$ & I09T 464C & 395 & 57 & 35 \\
\hline Mal d I.04-4 & $\begin{array}{l}\text { F: CAAGGAAGAGCATGTTAAAGT } \\
\text { R: AGGGTAACACACAAATTACATG }\end{array}$ & $516 \mathrm{~A}, 518 \mathrm{~T}$ & 136 & 60 & 35 \\
\hline Mal d I.06C020I-2 & $\begin{array}{l}\text { F: CCACCATTTTCTCCATTAACTTCA } \\
\text { R: GCCTTAACATGCTCTTCCTTGATT }\end{array}$ & $221 \mathrm{~A}$ & 360 & $62 / 60$ & $5 / 35$ \\
\hline Mal d I.06A-SSRe & $\begin{array}{l}\text { F: GGTGAAGGTTAGTTTAATTTCCACA } \\
\text { R: GTTTCACATAGCTGTATTCACTCCCT }\end{array}$ & (CA) SSR & & 60 & 30 \\
\hline
\end{tabular}

\footnotetext{
a Names are according to Table I;

bPosition refers to the genomic sequence counted from the ATG starting codon;

$c, d$ PCR annealing temperature $(T m)$ and number of cycles, respectively. In case of two values, a touch-down PCR was performed in two steps.

e Note that although the SSR marker for Mal d I.06A is gene specific, its is not sequence specific. In cases where a marker allele could be derived from both parents, linked markers have been used to assess the inheritance of protein variants to cultivars.

${ }^{f}$ Nucleotides that are italicized were added to the 5 ' end of the initial primer to obtain the sequence GTTT, which serves a pig-tail [3I].
}

were expressed as a percentage of the response against the reference cultivar Golden Delicious. The final ranking results were obtained by averaging the responses from four different experiments. This study was reviewed and approved by the Ethics Committee of the University Medical Center Utrecht under document number 01-050. All patients provided written informed consent before enrolment in the study.

\section{Authors' contributions}

LJWJG and KHS initiated this study. LJWJG, KHS, EVW and ZSG designed the experiment. ZSG, CIM and PA performed the gene cloning and sequences analysis. STHPB and ACK conducted the skin prick experiments. YHL tested and analysed the SSR markers. EVW performed the association analyses. ZSG, EVW, PA and LJWJG drafted the paper.

\section{Acknowledgements}

This study has been carried out with financial support from the Ministry of Agriculture, Nature and Food Quality of The Netherlands, from the China III Project (B060/4) and from the Commission of the European Communities for the projects SAFE (QLKI-CT-2000-01394) and ISAFRUIT. ISAFRUIT is funded under the Thematic Priority 5-Food Quality and Safety of the $6^{\text {th }}$ Framework Programme of RTD (Contract no. FP6-FOOD-CT2006-016279). The views and opinions expressed in this publication are purely those of the writers and may not in any circumstances be regarded as stating an official position of the European Commission and in no way anticipates its future policy in this area.

\section{References}

I. Eriksson NE, Formgren $\mathrm{H}$, Svenonius $\mathrm{E}$ : Food hyper-sensitivity in patients with pollen allergy. Allergy 1982, 37:437-443.

2. Ebner C, Birkner T, Valenta R, Rumpold H, Breitenbach M, Scheiner O, Kraft D, Sakamoto T, Hayashi Y, Yamada M, Torii S, Urisu A, Vieths S, Schoning B, Petersen A, Janek K, Aulepp H, Rudeschko O, Fahlbusch B, Henzgen M, Schlenvoigt G, Herrmann D, Jager L: Common epitopes of birch pollen and apples: Studies by Western and Northern blot. J Allergy Clin Immunol 199I, 88:588-594.

3. Vieths S, Janek K, Aulepp H, Petersen A: Isolation and characterization of the I8-kDa major apple allergen and comparison with the major birch pollen allergen (Bet $\mathbf{v}$ I). Allergy 1995 , 50:42I-430.

4. Schoning B, Ziegler WH, Vieths S, Baltes W: Apple allergy: the cDNA sequence of the major allergen of apple, determined by performing PCR with a primer based on the $\mathrm{N}$-terminal amino acid sequence, is highly homologous to the sequence of the major birch pollen allergen. I Sci Food Agri 1996, 71:475-482.

5. Vieths S: Allergenic cross-reactivity, food allergy and pollen. Environ Toxicol Chem 1997, 4:6I-70.

6. Holm J, Baerentzen G, Gajhede M, Ipsen H, Larsen JN, Lowenstein H, Wissenbach M, Spangfort MD: Molecular basis of allergic crossreactivity between group I major allergens from birch and apple. J Chromatogr B 200I, 756:307-313.

7. Vieths S, Jankiewicz A, Schoning B, Aulepp H: Apple allergy: the IgE-binding potency of apple strains is related to the occurrence of the 18-kDa allergen. Allergy 1994, 49:262-27I.

8. Hsieh LS, Moos M, Lin Y: Characterization of apple 18 and 31 kd allergens by microsequencing and evaluation of their content during storage and ripening. J Allergy Clin Immunol 1995, 96:960-970

9. Bolhaar STHP, Weg WE van de, Van Ree R, Gonzalez-Mancebo E, Zuidmeer L, Bruijnzeel-Koomen CAFM, Fernandez-Rivas M, Jansen J, 
Hoffmann-Sommergruber K, Knulst AC, Gilissen LJW]: In vivo assessment with prick-to-prick testing and double-blind, placebo-controlled food challenge of allergenicity of apple cultivars. J Allergy Clin Immunol 2005, I I 6(5): 1080-1086.

10. Kootstra HS, Vlieg-Boerstra BJ, Dubois AEJ: Assessment of the reduced allergenic properties of the Santana apple. Ann Allergy Asthma Immunol 2007, 99:522-525.

II. Son DY, Scheurer S, Hoffmann A, Haustein D, Vieths S: Pollenrelated food allergy: Cloning and immunological analysis of isoforms and mutants of Mal d I, the major apple allergen, and Bet v I, the major birch pollen allergen. Eur J Nutri 1999, 38:20I-2I5.

12. Ferreira F, Hirtenlehner K, Jilek A, Godnik CJ, Breiteneder H, Grimm R, Hoffmann Sommergruber K, Scheiner O, Kraft D, Breitenbach M Rheinberger Hans J, Ebner C: Dissection of immunoglobulin $\mathbf{E}$ and $T$ lymphocyte reactivity of isoforms of the major birch pollen allergen bet $\mathbf{v} \mathrm{I}$ : Potential use of hypoallergenic isoforms for immunotherapy. J Exp Med 1996, 1 83:599-609.

13. Ma Y, Gadermaier G, Bohle B, Bolhaar S, Knulst A, Markovic-Housley Z, Breiteneder H, Briza P, Hoffmann-Sommergruber K, Ferreira F: Mutational analysis of amino acid positions crucial for IgEbinding epitopes of the major apple (Malus domestica) allergen, Mal d I. Int Arci Allergy 2006, 139:53-62.

14. Atkinson RG, Perry J, Matsui T, Ross GS, MacRae EA: A stresspathogenesis-, and allergen-related CDNA in apple fruit is also ripening-related. NZ J Crop Hort Sci 1996, 24: I03-107.

15. Gao ZS, Weg WE van de, Schaart JG, Schouten HJ, Tran DH, Kodde L, Meer IM van der, Geest AHM van der, Kodde J, Breiteneder $\mathrm{H}$ Hoffmann-Sommergruber H, Bosch D, Gilissen LJWJ: Genomic cloning and linkage mapping of the Mal $I$ I (PR-IO) gene family in apple (Malus domestica). Theor Appl Genet 2005 III:171-183.

16. Puehringer H, Zinoecker I, Marzban G, Katinger H, Laimer M: MdAP, a novel protein in apple, is associated with the major allergen Mal d I. Gene 2003, 32I:I73-I83.

17. Beuning LL, Bowen JH, Persson HA, Barraclough D, Bulley S, MacRae EA: Characterisation of Mal d I-related genes in Malus. Plant Mol Biol 2004, 55:369-388.

18. Helsper JPFG, Gilissen LJW], van Ree R, America Antoine HP, Cordewener Jan HG, Bosch D: Quadrupole time-of-flight mass spectrometry: A method to study the actual expression of allergen isoforms identified by PCR cloning. J Allergy Clin Immunol 2002, I 1 0:131-138.

19. Weg WE Van de, Voorrips RE, Finkers R, Kodde LP, Jansen J, Bink MCAM: Pedigree genotyping: A new pedigree-based approach of QTL identification and allele mining. Acta Hortic 2004, 663:45-50.

20. Schenk MF, LJWJ Gilissen, GD Esselink, MJM Smulders: Seven different genes encode a diverse mixture of isoforms of Bet $v I$, the major birch pollen allergen. BMC Genomics 2006, 7:168

21. Vanek-Krebitz M, Hoffmann-Sommergruber K, Laimer da Camara Machado M, Susani M, Ebner C, Kraft D, Scheiner O, Breiteneder H: Cloning and sequencing of Mal $\mathrm{d} \mathrm{I}$, the major allergen from apple (Malus domestica), and its immunological relationship to Bet v I, the major birch pollen allergen. Biochem Biophys Res Commun 1995, 21 4:538-55I.

22. Gao ZS, Weg WE Van de, Schaart JG, Van Arkel G, Breiteneder H, Hoffmann-Sommergruber K, Gilissen LJWJ: Genomic characterization and mapping of the apple allergen genes Mal $d 2$ (thaumatin-like protein) and Mal d 4 (profilin). Theor Appl Genet 2005, III: 1087-1097.

23. Neudecker P, Schweimer K, Nerkamp J, Scheurer S, Vieths S, Sticht $H$, Rösch P: Allergic cross-reactivity made visible: solution structure of the major cherry allergen Pru av I. J Biol Chem 200I, 276:22756-22763

24. Botton A, Lezzer P, Dorigoni A, Barcaccia G, Ruperti B, Ramina A: Genetic and environmental factors affecting allergen-related gene expression in apple fruit (Malus domestica L. Borkh). J Agric Food Chem 2008, 56:6707-6716.

25. King TP, Hoffman D, Lowenstein H, Marsh David G, Platts Mills Thomas AE, Thomas W: Allergen nomenclature. J Allergy Clini Immunol 1995, 96:5-14.

26. Drenkard E, Richter BG, Rozen S, Stutius LM, Angell NA, Mindrinos M, Cho RJ, Oefner PJ, Davis RW, Ausubel FM: A simple procedure for the analysis of single nucleotide polymorphisms facili- tates map-based cloning in Arabidopsis. Plant Physiol 2000, 1 24: | 483-1492

27. Gao ZS, Weg WE Van den, Schaart JG, Meer IM Van der, Kodde L, Laimer M, Breiteneder H, Hoffmann-Sommergruber K, Gilissen LJWJ: Linkage map positions and allelic diversity of two Mal d 3 (non-specific lipid transfer protein) genes in the cultivated apple (Malus domestica). Theor Appl Genet 2005, I I 0:479-49 I.

28. Dreborg S, Foucard T: Allergy to apple, carrot and potato in children with birch pollen allergy. Allergy 1983, 38:167-I72.

29. Dreborg S: EAACI position paper. Allergy 1993, 48(suppl 14):49-82.

30. Poulsen LK, Liisberg C, Bindslev-Jensen C, Malling HJ: Precise determination of skin-prick tests: validation of a scanning device and software for a personal computer. Clin Exp Allergy 1993, 23:6I-68.

3I. Brownstein MJ, Carpten JD, Smith JR: Modulation of nontemplated nucleotide addition by tag DNA polymerase: primer modifications that facilitate genotyping. Biotechniques 1996 , 20:1004-1010.
Publish with Bio Med Central and every scientist can read your work free of charge

"BioMed Central will be the most significant development for disseminating the results of biomedical research in our lifetime. "

Sir Paul Nurse, Cancer Research UK

Your research papers will be:

- available free of charge to the entire biomedical community

- peer reviewed and published immediately upon acceptance

- cited in PubMed and archived on PubMed Central

- yours - you keep the copyright 